\title{
European Security: New Challenges and Prospects for Co-operation
}

\begin{abstract}
New threats after the Cold War have imposed a claim for new instruments of prevention and defense, consequently changing security relations between states and their co-operational perspectives. The future of European security had become very obscure.

Observing the complexity and multitude of various processes on the global stage as well as crucial changes in the international system and aiming to better understand European security perspectives in this chaotic environment, institutionalization of the European security system, was chosen as the main object of this article.

The main purpose of the article is to estimate the process and perspectives of the institutionalization of the European security system. The first part of the article is devoted to major changes in the global security agenda after the Cold War. Factors, which influence or might influence security of the European region, are identified. Analysis of possible institutionalization of the regional security system in Europe is conducted in the second part. In two last parts the article looks at the opportunities of the NATO and the EU to become the cornerstones of an effective European security system.
\end{abstract}

European history is a history of the rise and fall of civilizations, a history of permanent wars, conflicts, peace agreements, state coalitions, etc. Major developments in Europe have always had a strong influence on other parts of the world. Europe can also be associated with culture, progress and values that for centuries have influenced the development even of the farthest corners of the planet. For a long time European security was related to the stability and peace within Europe. Europe was considered secure if major European powers were in peace among themselves. Events of XX century, however, urged to reconsider the perspectives of European security. First of all, Europe became divided into two antagonistic blocks of the East and the West. Secondly, the significance of other regions to European security relatively increased.

During the Cold War the scheme of European security was comparatively clear and was based on deterrence policy of two hostile camps. Two military alliances were functioning in the region. Security identity of European countries depended on their affiliation with a certain block. Each block had clear enemies and clear threats. The cooperation inside the block was maintained trying to ensure an adequate response to the threats stemming from the other block. The alliance was a possibility to

Margarita Šešlgyte - Lecturer of the Political Science Department of the Lithuanian Military Academy, Ph. D. candidate of the Institute of International Relations and Political Science of the University of Vilnius. Address: Šilo 5a, LT-2055 Vilnius, Lithuania, tel. +370-5-2127970, e-mail: margo_ses@yahoo.com 
mobilize and pool common resources to fight for a common purpose. At the end of the Cold War the disappearance of a clear enemy ruined the identity of the communist block, which had been maintained by forceful means. The end of the bipolar world order also aggravated problems, which had emerged as consequences of technological advance and globalization. During the Cold War those problems were constrained by deterrence policy and came into light when the significance of this poucy diminished. Thus, after the Cold War the problematique of security expanded into the areas earlier assumed as marginal ones. International migration, international crime, globalization of ecological problems, rapidly expanding economic crises, social instabilities, ethnic conflicts, terrorism became the main challenges for security and stability in Europe and in the rest of the world.

The new threats have imposed a claim for new instruments of prevention and defense, consequently changing security relations between states and their co-operational perspectives. The future of European security had become very obscure.

Observing the complexity and multitude of various processes on the global stage as well as crucial changes in the international system and aiming to better understand the perspectives European security in this chaotic environment, European security or, to be more precise, institutionalization of the European security system, was chosen as the main object of this article. However, the concept of European security is very complicated in itself. Two major problems related to the definition of European security might be pointed out. The first one is an ambiguity of the security definition and the second one is a variety of competing concepts of Europe.

Security analysis in general terms is conducted by answering three basic questions: 1) what is to be secured?;2) what are the threats? and finally 3 ) how is security attained? In other words, it is a study of threat management and use of security measures. A classical definition of security states that security is the absence of a direct military threat for a state's sovereignty and territorial integrity. However, a contemporary concept of security is much wider than the classical one. It defines security as the absence of threat to existing values. Nevertheless, due to the limitations of the volume, the article mainly concentrates on the analysis of freedom from direct coercion as the major value to be protected.

The answer to the question 'What is to be secured?' is related to the choice of the analysis level. The most widely used scheme of security analysis contains five major security levels: international systems, international sub-systems, units, subunits and individuals ${ }^{1}$. The choice of the level defines the object of the study. It should be also noted that because of the complexity of contemporary security, a distinctive line between levels is very blur. Events on the global arena can cause a reaction on an individual level and vice versa. Although the analysis of European security requests concentration on the regional security level, globalization and an increasing interdependence among states make an exceptionally regional analysis of not full value. It is impossible to understand European security without a wider insight, which includes the analysis of the main global security trends and their implications on the regional level. Therefore major global security trends are also debated in the actide.

${ }^{1}$ Buzan B., Waever O., de Wilde J., Security: a New Framework for Analysis, Lynne Riener Publishers Inc. 1988, p.6. 
Trying to define the borders of the region concerned, one has to take into account the complexity of the concept of Europe. Various historical, cultural, political and institutional factors determine different definitions of the region. With regard to Europe, which extends from Vancouver to Vladivostok, it is understood in the framework of the Organization for Security and Cooperation in Europe (OSCE). Geographical criteria limit Europe with the Atlantic Ocean on one side and the Ural mountains on the other. In a political sense, Europe is identified with respect of human rights, consolidated democracy and functioning free market. Limits of this identity are the borders of the European Union (EU) and the North Atlantic Treaty Organization (NATO). The article bases on the political definition of Europe, which also includes candidate countries. Countries which at least in the nearest future will not become EU or NATO members, but whose security is inseparable from common European security is also be discussed in the article.

The main purpose of the article is to estimate the process and perspectives of the institutionalization of the European security system. The first part of the article is devoted to major changes in the global security agenda after the Cold War. Factors that influence or might influence security of the European region are identified. Analysis of possible institutionalization of the regional security system in Europe is conducted in the second part. In two last parts the article looks at the opportunities of NATO and the EU to become the cornerstones of an effective European security system.

\section{Global trends in the international system: impact on European security}

The world after the Cold War became a chaotic entity moving in an uncertain direction. It was difficult to understand in this turmoil who was a friend and who was an enemy, with whom one had to cooperate and who was supposed to be a threat. After the Cold War scientists of international relations almost unanimously announced that the international system ${ }^{2}$ changed. All categories of the international system were modified at the end of the Cold War: capacity and intensity of states' interactions, processes, units and structures ${ }^{3}$. However, the same scientists failed to agree on major features of the newly emerging international system. Thus, there are still a lot of competing images of the contemporary international system. After September 11 several authors claimed that the post-Cold War international system and world or$\mathrm{der}^{4}$ were changing again and that yet another new world order was emerging ${ }^{5}$. However, it is more likely that the events in New York and Washington DC are not to be perceived as the causes of major changes in the international system and world order,

\footnotetext{
${ }^{2}$ International system - the network of relations which exists at the international level. In Berridge G. R., James A. ed. A Dictionary of Diplomacy, Palgrave, N.Y., 2001, p.135.

${ }^{3}$ Buzan B., Little R., International Systems in World History: remaking the study of international relations, Oxford University Press, 2000, p.3.

${ }^{4}$ Changes in world orders usually implies fundamentally new framework of rules and philosophy for how international affairs are conducted. Davies J. L., The Future of Our New World Order http:// www.civic.webs.com/cwvlib/now/article_1/now_1_definition.html

${ }^{5}$ Heisbourg F., "Europe and the Transformation of the World Order", http://www.eusec.org/ heisbourg/htm
} 
they rather only prompted processes that had already started after the Cold War (or even during the Cold War). These processes, in their turn, might be understood as a long-lasting transition from the old world order to the new one that due to the multiplicity of factors involved, which are interacting and moving in various directions, have not acquired a clear shape yet. Several trends in international surroundings and interstate relations therefore deserve a special attention as the ones that will undoubtedly affect the shape of the new world order, the roles of states, their interactions and security.

First of all, the speeding up globalization affects non-state actors so that they are increasing both in their number and power. These actors are acting in very interrelated post-industrial societies. Globalization for a long time was perceived as a possible source of peace and progress; it turned out, however, that it also had negative consequences. The effects of globalization were not equal to everyone. While one part of the world was enjoying economic prosperity, scientific and technological progress, security, etc., the other one continued to live below the poverty line and was suffering from famine, diseases and violence of authoritarian regimes. The world once again seem to be splitting into two parts: winners and losers. The disappointment of the losers began to express itself in different forms of violence: mass demonstrations, destruction, terrorist attacks. Violence turned towards Western democracies globally enforcing their values and changing traditional political, economic and social systems of underdeveloped countries. Seeking to implement the idea of democracy universally, democratic states created a new enemy which, although neither powerful nor rational, but combining traditional values and technological advances, became a serious challenge to the democratic world. On September 11 the democratic world faced a threat, which was different from the traditional ones, especially in terms of destructive power and uncertainty. The fact that the most powerful state was chosen as a target demonstrates that an uncontrolled expansion of those threats does not have any limits and that even the most powerful countries cannot feel secure.

Barry Buzan claims that a two-fold world is emerging after the Cold War. This world consists of two very diverse parts: one part is an economically strong and democratic center, the other one is a non-democratic economically underdeveloped and chaotic periphery. XXI century has posed a new challenge for the democratic world - to control the chaos arising in the periphery ${ }^{6}$. B. Buzan thinks that the main mission of center states, which can also be called a mature anarchy ${ }^{7}$, therefore is to assure stability both in the center and in the periphery. Only center states, if acting together, taking advantage of modern security ensurance means and pooling up their financial resources, are capable of stopping the expansion of post-modern threats ${ }^{8}$, basically stemming from the periphery. Thus, security of the world depends on the efforts, determination and solidarity of center states in fighting those threats, also cooperating with countries of the periphery.

\footnotetext{
${ }^{6}$ Van Ham P., Kugler R. L., "Western Unity and the Transatlantic Security Challenge", Marshall Center Papers, http://www.marshallcenter.org/CISS/English/Mcpapers, p. 41.

${ }^{7}$ Buzan B., "Security, the State, the "New World Order" and Beyond" in Lipschutz R. D. ed., On Security, NY: Columbia University Press, 1998, p. 41.
} 
A second important feature illustrating the world after the Cold War is the unprecedented speed of technological advance and the diminishing significance of space and time. Natural barriers and long distances do not protect countries from external threats any more. New means of communication have made the world much smaller. A relaxed control of state borders has triggered the intensification of transborder economic, political, financial and social flows. An uncontrolled expansion of negative phenomena related to those flows has become yet another challenge to the post-Cold War world.

Intensifying interactions among states and non-state actors, blurring border lines between the internal and external policy have caused the necessity to reconsider the strict division between direct military threats and marginal ones associated with non-military security aspects. In the contemporary world they often overlap. New types of threats that came into light after the Cold War also proposed a search for new means to fight them. It was necessary to make a reevaluation of military strategies and structures.

In the Balkans both Europeans and Americans realized that armed forces of the major European security organization NATO were not ready to deal with regional conflicts ${ }^{9}$. The military campaign in Afghanistan just reaffirmed the suspicion that new-type armed forces were necessary to deal with conflicts in the post-Cold War era. Politicians and military officers agreed that most of new missions had to be carried out by special forces equipped with the most modern technological armaments. They also recognized the significance of modern air forces in the new missions $^{1}{ }^{1}$. New military strategies became related to the Revolution in Military Affairs $(\text { RMA })^{11}$.

In order to restructure military capabilities adapting them to the contemporary needs of security, major reforms of the military sector are to be introduced and defense expenditure increased. However, not every country is determined to take those necessary steps. European Union countries are especially sensitive regarding any increase of defense expenditure, thereby enlarging the gap, which has already existed between USA and European military capabilities, especially in terms of modern technologies. The constantly increasing USA military advance might become a serious obstacle to common Euro-American military operations even in the framework of NATO. Outdated armed forces and armaments together with insufficient financing not only complicate joint actions of the allies, but also threaten the firmness of the transatlantic link, which is the cornerstone of international stability.

\footnotetext{
${ }^{8}$ Geroid Tuathail describes post-modern threats as a new "global" category of threats, dangers and risks assosiated with globalization, informationalization, the end of the Cold War, and the contradictions, broadly described as "environmental" generated by the triumphs of modernity, in Tuathail G. "De-teritorialized threats and global dangers: geopolitics and risk society, http://www.majbill.vt.edu/geog/faculty/total/papaers/newman.html

9 "Peacekeeping Not NATO's Job says Cohen", Press Advissory: Basic Publications, 16 July 1999, http://www.basicint.org/pr_natopk.html

${ }^{10}$ Adams G., "Convergence or Divergence? The Future of the Transatlantic Defence Industry" in Duke S., ed., Between Vision and Reality: CFSP's Progress on the Path to Maturity, Maastricht: European Institute of Public Administration, 2000, p.180.

${ }^{11}$ RMA means sophisticated management, control, communication, computers, intelligence, surveillance, reconnaissance, data links and precision guided munitions.
} 
In the context of the newly emerging world order, the changing balance of power and the altering global security problematique status of Europe in the world and its security perspectives have also to be reconsidered. During the Cold War the European security system was characterized by the effect of suppression or voluntary obedience ${ }^{12}$. Security interests of (West) European countries were subordinated to the security orientation of the dominating power (the USA), which deployed its military bases in the region. K. M. Fierke has compared this structure to a family ${ }^{13}$ which, restrained by NATO, was the main guarantor of European security during the Cold War. After the Cold War relations between the USA and Europe began to deteriorate and there was an observable anxiety regarding the perspectives of the Euro-American partnership and its influence on European or even global security and stability. It was thought that frequent disagreements between Europeans and Americans might turn the 'center' block into a victim of inner contradictions and weaken its power, which is of the utmost importance in the face of post-modern threats. However, in order to estimate the validity of these fears, the main sources of disagreements between Europeans and Americans have to be considered.

First of all, Europeans are not satisfied with the unilateral policy of the USA in the international arena. Unilateral actions and renouncement of international commitments might endanger international regimes, which reflect long-term efforts of the world community to maintain at least a minimal degree of certainty in the anarchic international environment. The unilateral policy of the USA in Europe is perceived as an erosion of the cornerstones of European security: international law and order. In this light, the USA military campaign in Iraq is tobeconpered as an important test for the transatlantic link.

Another test for the European - USA friendship may be the Anti-Missile Defense (AMD) system, which will also have inevitable consequences for European security. The AMD will change the European nuclear balance placing European countries at a disadvantaged position, also providing them with new obligations and new dangers. The installation of the AMD also means the end of NATO as a nuclear alliance, hence aggravating disagreements in NATO structures. Most European countries perceive the Treaty on Anti-Ballistic Missiles as a basis for international disarmament and fear that the AMD might ruin the fragile regime of arms control and non-proliferation. The installation of the AMD would reduce the European - American interoperability in the future both in assuring global security and also defending Europe. As soon as the AMD system starts to function, the ability of European countries to join American military coalitions will diminish as Europeans will not be protected against the counter-attacks of so-called rogue states including strokes with weapons of mass destruction (WMD).

Secondly, although the USA and the EU remain the closest partners in the economic domain, disagreements or even serious quarrels of economic origin are becoming more frequent. It is likely that the growing EU economic potential will just stimulate these disagreements.

\footnotetext{
${ }^{12}$ Buzan B., Žmonès, valstybès ir baimè: Tarptautinio saugumo studijos po šaltojo karo, Vilnius: Eugrimas, 1998, p.278.

${ }^{13}$ Fierke K. M., "Changing worlds of security" in Critical Security Studies: Concept and Cases 8, 1997, p. 230.
} 
Some scientists of International Relations tend to explain contradictions between the USA and Europe referring to different images of the international system ${ }^{14}$, which cause, in their turn, different approaches to international cooperation, different interpretations of international law and, finally, different definitions of threats and means to fight them. Europeans do not recognize the traditional definition of power and condemn any expression of violence. It might be observed that Europe is becoming a relatively isolated entity relying on rule of law, good will and cooperation where violence is not tolerated, human rights are respected, and welfare is guaranteed to all citizens. Robert Kagan has compared this entity to a post-historic welfare heaven, "eternal peace" of Kant ${ }^{15}$. Europeans live (or at least used to live) a secure life inside their own world having a NATO shield to protect them from external threats. However, the model which functions effectively in Europe does not fit for the rest of the world where many non-democratic states, causing a lot of insecurity challenges, still exist. Therefore Americans tend to rely on another vision of the world, which might be yet compared to the anarchic world of Hobbes ${ }^{16}$, where international law is ineffective, agreements between states are neither respected nor trusted and security is based on military power.

However, the unilateral policy of the USA, the disagreements of economic origin and the ideological gap may only partly explain misunderstandings between the allies in the security domain. Yet another important factor causing different understandings of the world and different actions of the allies is a shift of political and military power towards the USA. Europeans, who lag behind Americans in the military domain, due to their military inability are more preoccupied with problems that might be solved by political means and huge financial resources ${ }^{17}$. The asymmetry in military power also causes a different understanding of threats. A weaker Europe faces less threats than the powerful and globally acting US. Types of threats also differ. On the one hand, the most important ones for Americans are: proliferation of weapons of mass destruction, terrorism, unstable states. On the other hand, Europeans stress the importance of ethnic conflicts, migration, organized crime, poverty and environmental problems. It is likely therefore that different security interests and definitions of threats in Europe and the US have to be related more to European capabilities rather than to cultural, economic and philosophical factors.

Responding to the fastening globalization, democratic states will have to think and act more globally when forming their national security and foreign policies. Europeans also would be forced to change their strategies of the Cold War and increase their contributions to global security. However, it does not mean that Europeans have to completely devote themselves to the military aspects of security. USA Senator Richard Lugar ${ }^{18}$ in March 2002 admitted, that Europeans would pay the biggest share of the Afghanistan reconstruction bill. Europe also takes care of the most financial aid and development programs in the Middle East, Asia and Africa provi-

\footnotetext{
${ }^{14}$ Kagan R., "Power and Weakness", http://www.policyreview.org/JUN02/kagan_print.html

${ }^{15}$ Kagan, (note 14 ).

${ }^{16}$ Kagan, (note 14).

${ }^{17}$ Kagan, (note 14).

${ }^{18}$ Lugar R.G., "NATO after 9-11: Crisis or opportunity?” March 4, 2002, http://www.senate.gov/

$\sim$ lugar/.
} 
ding non-military means necessary to ensure security, which are particularly significant for a full security policy cycle. It is even more important that Europeans would continue providing non-military instruments rather than re-orienting themselves towards the completely military strategies. Underestimation of non-military security aspects might lead to the realization of pessimist predictions of some International Relations scientists presuming that the end of the world will come not as a war between civilizations, but as a riot of the poorest nations against the rich countries as predicted by Marx ${ }^{19}$. Even the largest military resources will be of no use trying to suppress this riot.

Both Americans and Europeans realize the necessity of mutual cooperation, trying to control the threats stemming from the non-democratic periphery. As the USA is important for Europe because of military security guarantees, Europe is useful for Americans because of its growing political and economic influence and also of non-military instruments of security. Therefore, it is likely that the contradictions between the allies, which came into light after the Cold War, will not ruin the vitally important for both sides transatlantic partnership. It might be assumed that the cooperation between Europe and the USA in the security field will be maintained and will be carried out on the basis of labor division, taking advantage of the areas where countries have the best potential.

After the Cold War one of the superpowers ceased to exist. Russia took over the rights of the former USSR but did not inheritate the same status and power. Nevertheless, Western countries still looked at Russia with uncertainty. Russia was difficult to understand and predict. Western countries could never be sure of the direction of Russian foreign and security policies. It was impossible to predict whether Russia would choose to cooperate with center states or together with unstable democracies (many of them are still strategic partners of Russia) would fight against the democratic world. Today Russia is drifting towards the West and is perceived as a more reliable partner as it used to be earlier. Still, estimating the possibilities and willingness of Russia to cooperate with Europeans, several important factors are to be taken into account. On the one hand, Russian foreign policy towards the West is strongly influenced by the Russian culture containing deep anti-Western traditions ${ }^{20}$. On the other hand, Russia has many problems in Asia related to the geographical extension of Russia. These problems induce Russia to cooperate with the West. Cooperative initiatives between Russia and Western Europe are also stimulated by a similar understanding of potential threats and measures to fight them ${ }^{21}$. The most dangerous threats for Russia today are the same post-modern threats Europeans face. Russia however is not able to fight them without the European aid, especially the financial one. Thus, cooperation with Europeans in the economic, political and military fields is in Russia's interests.

Although, the ambitions to regain the super-power status are still vivid in some political and military spheres Russia has ceased to be a superpower. It has become a regional power: still strong enough to protect itself from external enemies,

\footnotetext{
${ }^{19}$ Lindley-French J., "Terms of Engagement: the paradox of American power and the transatlantic dilemma post-11 September", Chaillot Paper No.52, 2002 May, p.15.

${ }^{20}$ MacFarlane S. N., "Russia, the West and Europe Security", Survival, 1993 Autumn, p.10.

${ }^{21}$ Тренин Д., Россия и основные институты безопасности в Европе вступая в ХХІ вэк, Москва, 2000, с.88.
} 
however weak economically and lacking resources to solve problems related to the internal stability and welfare ${ }^{22}$. Although Russia is experiencing enormous economic difficulties, which in their turn cause the backwardness of the military complex, and it is not perceived as a direct threat in the West anymore, the danger of postmodern threats coming from Russia has just increased. Safe Europe is impossible without safe Russia ${ }^{23}$, therefore, Russia has to be included rather than excluded from European or global security systems. Thus, European countries have to be especially interested in cooperation with Russia. The areas for potential cooperation in the security domain between Russia and both the USA and Europe are constantly growing $^{24}$, and Russia has good chances of becoming an important pillar of European security.

Nevertheless, it is too early to claim that positive changes in the RussianWestern relations are long-termed. Some of the so-called rogue or unstable states are strategic allies and trade partners of Russia, and there are no signs that Russia dissociates from them. No one can be sure that the ambitions to regain the superpower status would not become prevailing among the political or military elite. On the optimistic note, shift towards the West was not so sudden and might be seen as a part of a wider strategy perfectly matching the general program of economic and social reforms. As far as the reforms would remain a priority for the political elite in Russia, good relations with the West are almost granted.

Summarizing, it could be stated that European security on the global level essentially depends on common efforts and the success of center states aiming to neutralize negative consequences of globalization and the results of cooperation between center and periphery states in political, economic and security areas.

\section{Prospects of the regional security system in Europe}

Although security levels overlap very frequently, in the contemporary world events on the global stage have significant consequences on the regional or even individual level and vice versa, the best way to analyze the prospects of institutionalization of the European security system is to rely on the regional security level, yet taking into account global security trends. The classical security complex theory ${ }^{25}$ claims that every region is composed of various complexes of states: friends and enemies, potential friends and potential enemies. A security complex might be defined as a group of states sharing the same understanding of security and the same threats. Security of those countries is indivisible and is to be analyzed integrally ${ }^{26}$. Although it might be assumed that Europe is composed of several security comple-

\footnotetext{
${ }^{22}$ Kremenyuk V., "Changes in European Security Landscape: a Russian View", http://www.eusec.org/kremenyuk.htm

${ }^{23}$ Arnswald S., "EU Enlargement and the Baltic States: the Incremental Making of New Members" Programme of the Northern Dimension of the CFSO, vol.7, Helsinki: The Finish Institute of International Affaires, 2000, p.105.

${ }^{24}$ Trenin D, "Russia - within - Europe: working toward a new security arrangement" http://www.eusec.org/trenin.htm

${ }^{25}$ Buzan, Waever, de Wilde, (note 1) p. 11.

${ }^{26}$ Buzan, Waever, de Wilde, (note 1) p. 12.
} 
xes, due to the intensifying interactions among European countries and the growing importance of de-territorialized post-modern threats, the best way European security could be analyzed is as a security of a single entity, a security of the European security complex. B. Buzan describes Europe as a regional system, because power relations and ties of escalation interlink European countries into a single entity ${ }^{27}$. Historical, cultural, economic and political ties connect countries of the same region, and contemporary threats prompt them for even a broader and deeper cooperation. States cannot deal with threats, which are not constrained by state borders and expand extremely fast, on their own. Security can only be achieved in close co-operation of all countries of the region. However, attention should be paid to sub-regional dividing lines in Europe, which may indicate different levels of security and insecurity inside the region. To this purpose, Europe could be divided into three sub-regions: Western Europe (in the Cold War definition), candidate countries of Central and Eastern Europe, countries, which at least in the nearest future will not become EU or NATO members, but whose security is inseparable from common European security (Russia, the Ukraine, Belarus) and, finally, Balkan countries as a special case. Due to the events of the last decade, Balkan countries could only be analyzed as a periphery of Europe, which does not yet adhere (although some countries do, e. g. Slovenia, Croatia, etc.) to the criteria of the political definition of the European region, but yet are important for the overall security of the region and therefore have to be included into the emerging system of European security.

It is

not easy though to ensure an efficient cooperation in an anarchic international environment where there are so many conflicting interests and uncertainty. Usually institutions are considered as the most effective form of cooperation. In the international environment institutions play yet another role, they assure transparency in an anarchic international sphere and diminish negative consequences of the uncertainty trap. Thus, institutions are not only an opportunity to fight threats in common, but they also have a restricting effect. They affect strategies of states, provide them with opportunities to choose and, finally, change costs-profits scales. Institutions may vary from international conventions and regimes to formal organizations and might be considered more than the sum of common resources. On the international scene they become important variables in themselves.

peration among states in the security domain is important because of four major functions: 1) collective defense, 2) collective security; 3) security management and 4) out-of-area intervention ${ }^{28}$. Each of these functions involves different institutional mechanisms. If institutional capabilities do not correspond to the functions implemented, relying on an international organization might cause serious security problems. When obvious changes appear in the security agenda, states have to seek for new means to ensure security, reevaluating international surroundings and reconsi-

\footnotetext{
${ }^{27}$ Buzan (note 10) p.240.

${ }^{28}$ Tams C., "The Functions of a European Security and Defence Identity and its Institutional Form" in Haftendorn H., Keohane R.O, Wallander C. A ., ed., Imperfect Unions: Security Institutions over Time and Space, New York :Oxford University Press, 1999, p.81.
} 
dering national interests and foreign policy preferences of the most influential actors. Contemporary security policy is a long-term security building cycle, which

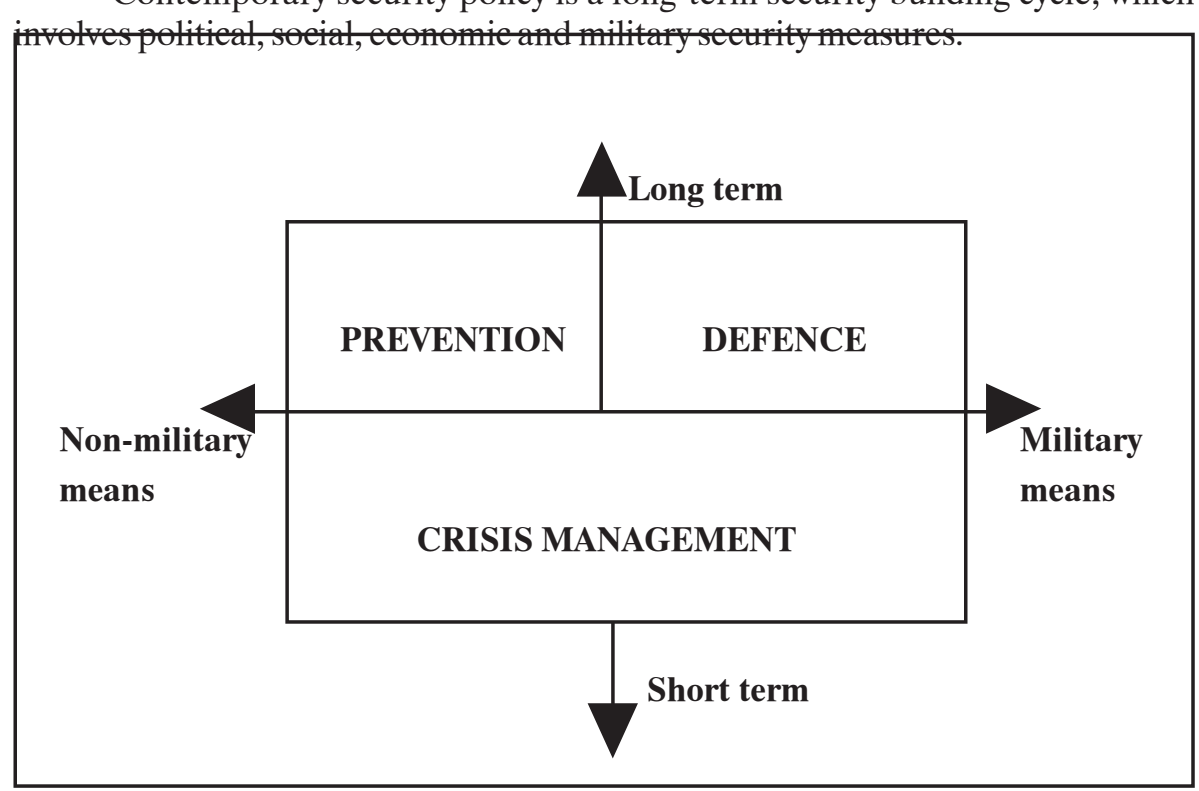

Functional dimensions of security policy

Keatinge P., European Security: Ireland's choices, Dublin: Institute of European Affairs, 1996, p.3.

Patrick Keatinge asserts that the cycle of contemporary security policy could be best explained dividing it into three functional dimensions: prevention, defense and crisis management. He believes that the contemporary security system in Europe might work on a similar basis as "Concert of Europe", relying however on a more complicated form, which involves multilateral institutions and non-state actors ${ }^{29}$. According to an ideal model of contemparary security policy, states cooperate on the basis of labor division that provides them with the advantages of the economy of scales in diplomatic, economic and military means and maximizes the ability of small states to become part of the security building process.

A long-term security policy today is closely related to the preventive measures of security and "civilian capabilities" (confidence building, cooperation etc.). Although defense and collective defense remain important instruments when fighting traditional threats, they become less relevant when actions are to be taken immediately. In these cases, crisis management instruments are preferred. Crises management instruments offer an entire spectrum of measures from a direct coercion to indirect restrictions in the framework of international organizations. It is important hence to find and maintain the right balance of various measures.

After the Cold War and the dissolution of the Warsaw Treaty Organization, the map of European security structures was reconsidered. It was assumed that a new security order had to be created on the overlapping structures of the EU, NATO, the

${ }^{29}$ Keatinge P., European Security: Ireland's choices, Dublin: Institute of European Affairs, 1996, p.3. 
Western European Union (WEU) and the Organization for Security and Cooperation in Europe (OSCE). Small roles in maintaining regional stability were envisaged for the Council of Europe (CE) and the Council of Baltic Sea Countries (CBSC) ${ }^{30}$. These organizations were expected to cooperate and provide a wide range of security instruments necessary to ensure a full security cycle. However, this new security architecture was based on Cold War organizations, which had been established to work in a completely different environment and to deal with threats of a different origin, thereforeit did not reflected chances in the security environment.

The inability of the existing structures to respond to new challenges and fulfill crisis management functions properly came into light in the Balkans. There was an observable inadequacy of norms, procedures, mechanisms and institutions. The events of September 11 just reaffirmed the unreadiness of the contemporary security system to neutralize new threats. It became obvious that the structures, objectives and instruments of the existing organizations did not correspond to the needs of XXI century and that it was necessary to search for more effective institutional forms.

Discussions on the necessity of new security institutions or reforms in the existing security system started immediately after the end of the Cold War. There was a wide agreement among security experts that the most proper system in the contemporary security environment was a cooperative security system. A cooperative security system is based on a bilateral and multilateral cooperation among states and institutions. It contains four interlinked security rings: individual security, collective security, collective defense and promoting stability ${ }^{31}$.

The individual security ring is basically related to promoting and protecting human rights within the boundaries of the system. The significance of this level especially increased in XXI century due to new trends in the interpretation of international law. During the last decade there have been many cases when the protection of human rights was perceived as a more important value than the territorial sovereignty of a state. These trends approximate the world to the Kantian vision of the world $^{32}$, where peaceful states in some cases are allowed to implement coercive actions against un-peaceful ones using illegitimate violence against their citizens.

The collective security ring concerns the maintenance of peace and stability within a common area. Organizations operating in a collective security ring are inward-oriented (UN, OSCE) and are meant to restrict members of the system, hereby differing from organizations of collective defense, which basically are outward-oriented and protect members of the organization from external threats. Some organizations encompass both rings of security (NATO). Properly functioning institutions of a collective security ring are very important dealing with post-modern threats, yet a collective defense ring is necessary when fighting traditional threats.

The essence of the ring of promoting stability is maintenance of stability in other regions using political, economic and, if necessary, military instruments. EU

\footnotetext{
${ }^{30}$ Winn N., "Europe: Old Institutions, New Challenges" in Jones C., Kennedy-Pipe C. ed., International Security in a Global Age: Securing the Twenty - first Century, London, Portland :Frank Cass Or., 2000, p.80.

${ }^{31}$ Cohen R., Mihalka M. Cooperative Security: New Horizonts for International Order, Garmish, Partenkirchen: George Marshall Center, 2001, p.1.

${ }_{32}$ Winn, (note 30) p.93-94.
} 
Commissioner on External Relations Christopher Patten in his speech on the changing security environment has noted that it does not matter how strong a state is, it could be the strongest one in the whole world, however it is not able to survive on its own. "Smart" bombs are important, however smart aid is even more important as it is also important to try to include unstable states into the international community rather than exclude them ${ }^{33}$. In the modern world, where the gap between rich democracies and poor unstable states of the third world is increasing this security ring gains a special significance.

Contemporary security, which faces both traditional and new post-modern threats, might be assured only combining all four rings of security. Hence, an effective security system in XXI century has to be able to work in all the directions that are listed above and provide necessary structures, institutions and instruments.

Table 1

Capabilities of existing security organizations to take part in

\begin{tabular}{|l|l|l|l|l|}
\hline Institution & $\begin{array}{l}\text { Individual } \\
\text { security }\end{array}$ & $\begin{array}{l}\text { Collective } \\
\text { Security }\end{array}$ & $\begin{array}{l}\text { Collective } \\
\text { defense }\end{array}$ & $\begin{array}{l}\text { Promoting } \\
\text { stability }\end{array}$ \\
\hline UN & Yes/No & Yes/No & No & Yes/No \\
\hline OSCE & Yes/No & Yes/No & No & Yes/No \\
\hline EU & Yes & Yes & No? & Yes/No? \\
\hline NATO & Yes & Yes & Yes & Yes? \\
\hline
\end{tabular}

\section{a cooperative security system}

Cohen R., Mihalka M. Cooperative Security: New Horizns for International Order, Garmish, Partenkirchen: George Marshall Center, 2001.

There are four major security institutions in Europe: the UN, the OSCE, NATO and still developing Common Security and Defense Policy (CSDP) of EU.

Taking a look at Table 1, it might be assumed that only NATO is capable of ensuring measures in all security rings ${ }^{34}$. However, the validity of this statement should not be overestimated. First of all, NATO was initially created as a collective defense organization, thus, trying to ensure security at all levels it has to change. On the other hand, the role of the EU, especially promoting stability in the regions outside Europe, is eventually becoming more distinct than that of NATO just it is not so evident. To promote stability, the EU uses non-military measures, which might be not so obvious as military ones, however still very important aiming to ensure that all stages of the security policy cycle are completed. An eventual development of EU common defense was also envisaged in the Maastricht Treaty ${ }^{35}$, thus, in a few years

\footnotetext{
${ }^{33}$ Freedland J. "Patten Lays into Bush's America”, The Guardian, February 9, 2002.

${ }^{34}$ Freedland, (note 33).

${ }^{35}$ The common foreign and security policy shall include all questions related to the security of the Union, including the eventual framing of a common defence policy, which might in time lead to a common defence. Treaty of EU, Maastricht, 1991, http://europe.eu.int/eur_lex/eu/treaties/index.html
} 
the EU might also be capable of taking collective defense ring tasks. Finally, due to the mixing up of the threats of the 4th and 5th Articles of the North Atlantic Treaty ${ }^{36}$, the definition of defense might be extended and include more aspects related to current activities of the EU. Still it is unlikely that at least in a short term the EU will be capable of ensuring security in the region without a major involvement of NATO and the US armed forces.

As far as there is no security organization fully matching the criteria of cooperative security and it is unlikely that any would be created soon, security in Europe can only be ensured by joint actions of the existing security organizations working on the basis of the division of labor. It could be noticed (Table 1) that just marginal roles in the cooperative security system of Europe are envisaged for the UN and the OSCE. These organizations due to the lack of political consensus are ineffective and basically implement functions of a political forum. On the other hand, in order to legitimate operations of NATO and the EU outside the region, a mandate of the UN is necessary (although not in all cases). The lack of a mandate however did not prevent NATO from carrying out military operations in the Balkans. Yet this precedent is not seen as an optimal solution, therefore, it is expected that the OSCE and the UN will continue the implementation of the legitimizing function in the newly emerging security system in Europe.

Karl Kaiser presents a scheme of the European defense system based on the division of labor between the two organizations ${ }^{37}$ (The some scheme was also proposed in 1999 in the Washington Summit):

ge-scale military operations - NATO forces under the USA command;

sile or air attack against European countries - NATO forces under the command of European countries (ESDI in NATO);

Small-scale military aggression, crisis management and military actions in areas not accessible for NATO due to the restrictions of the $5^{\text {th }}$ Article (EU CSDP).

Although this scheme of the defense ring may change, it is likely that the essence of the division of functions between NATO and the EU, where traditional defense remains the responsibility of NATO and the EU takes mainly Petersberg tasks, will be one of the major principles of the European cooperative security system. It is also likely that this model will be reflected in other security rings: the EU will be more attached to the civil and economic aspects of security and NATO will stick to military activities.

\footnotetext{
${ }^{36}$ Article 4: The Parties will consult together whenever, in the opinion of any of them, the territorial integrity, political independence or security of any of the parties is threatened. Article 5: The parties agree that an armed attack against one or more of them in Europe or North America shall be considered an attack against them all, and consequently they agree that, if such an armed attack occurs, each of them, in exercise of the right of individual or collective self-defence recognized by Article 51 of the Charter of the United Nations, will assist the Party or Parties so attacked by taking forthwith, individually, and in concert with the other Parties, such action as it deems necessary, including the use of armed force, to restore and maintain the security of the North Atlantic area. The North Atlantic Treaty, Washington DC, 4 April, 1949.

${ }^{37}$ Kaiser K., "Challenges and Contingencies for European Defense Policy", in Kaiser K ed. Towards a Common Defense Policy, Paris: WEU Institute for Security Studies, 1995, p.30.
} 
However, the efficiency of the cooperative security system depends not only on the proper functioning of certain organizations, but also on the results of their common actions. Aiming to make the EU - NATO cooperation function properly, a better coordination of EU and NATO activities is to be introduced. Robert Hunter emphasires that the cooperation between the EU and NATO has to be developed in six areas: 1) operational planning; 2) contingency planning; 3 ) planning of defense and capabilities; 4) procurement planning; 5) cooperation of the North Atlantic Council and the Political and Security Committee including members of Euro-Atlantic partnership countries; 6) common crisis management ${ }^{38}$. NATO and the EU have to use a common methodology for command, control, communications and intelligence. Coordination of enlargement processes might also positively influence prospects of cooperation. The success of the European cooperative security system will also depend on the results of the processes occurring in the EU and NATO: a) the results of NATO modernization and enlargement; b) the final product of CSDP development; c) consequences of EU enlargement ${ }^{39}$.

External and internal behavior of the most influential actors on the global and regional arena will also be reflected in European security prospects. It is likely that for ten or twenty years several categories of states will continue influencing security of the European region and therefore will be crucial actors of the European security system $^{40}:$ 1) the USA, 2) EU countries participating in NATO and CSDP and 3) states, which are impossible to integrate into NATO and the EU at least in the nearest future (some Balkan countries, Belarus, Russia and the Ukraine). The most important countries in the listed categories yet are: the USA, Great Britain, France, Germany and Russia. Although Russia was not always recognized as a European country, it undoubtedly has to be considered as part of the European security complex. Only involving Russia into common actions European security can be achieved.

Patrick Keatinge proposes three scenarios for European security. The developments of various scenarios depend on the configurations of three major variable

\begin{tabular}{|c|c|c|}
\hline $\begin{array}{c}\text { Consolidated cooperative } \\
\text { security }\end{array}$ & $\begin{array}{c}\text { Tentative cooperative } \\
\text { security }\end{array}$ & Adversial Europe \\
\hline $\begin{array}{c}\text { Comprehensive } \\
\text { democratization of Russia }\end{array}$ & $\begin{array}{c}\text { Transitional problems in } \\
\text { Russia }\end{array}$ & $\begin{array}{c}\text { Revanchist nationalism in } \\
\text { Russia }\end{array}$ \\
\hline $\begin{array}{c}\text { EU triumvirate in concert } \\
\text { (Great Britain, France, } \\
\text { Germany }\end{array}$ & Uncertain triumvirate in EU & Fragmented triumvirate in $\mathrm{EU}$ \\
\hline $\begin{array}{l}\text { Strenghtening co-ordination } \\
\text { within and between } \\
\text { multilateral institutions }\end{array}$ & $\begin{array}{l}\text { Competition or incoherence } \\
\text { between multilateral } \\
\text { institutions }\end{array}$ & $\begin{array}{l}\text { Optional resource to weak } \\
\text { multilateral institutions }\end{array}$ \\
\hline
\end{tabular}

groups (Table 2).

\footnotetext{
${ }^{38}$ Hunter R. E., European Security and Defence Policy: NATO's companion or competitor, RAND, 2002, p.158.

${ }^{39}$ Straw J., "Collective security in an enlarged Europe", Presentation at the conference at Intercontinental Hotel, Budapest, July 9, 2002, http:// www.Britain-info.org/defence/xq/asp/SarticleType/1/ Article_ID.2452/qx/articles_show.htm

${ }^{40}$ The USA as a NATO member directly participate in the regional security system.
} 


\section{Table 2}

\section{Three scenarios of European Security}

Keatinge P., European Security: Ireland's choices, Dublin: Institute of European Affairs, 1996, p.35.

Keatinge defines the contemporary European security system as a tentative one ${ }^{41}$, which probably will turn into a consolidated cooperative security system in the future.

Other important variables for the future European security system are: trends in global environment, namely, the ability of the international community to neutralize negative consequences of globalization, the success of the USA fighting global challenges, evolution of China and a lot of more factors which are still difficult to predict.

Security of Europe however cannot be isolated from the processes happening in the neighboring regions, therefore, it is crucially important to create modern structures for cooperation with states of other regions trying to include them, at least partly, into the system of cooperative security. Adam Rotfeld claims that the new post-Cold War security strategy of Europe has to include Asian countries (especially Pakistan, India and China $)^{42}$. Not all countries might be included into long-term cooperational structures though. A long-term cooperation is only possible among countries which are closely interconnected by firm political, economic and other links, have common identity, common rules, laws and common institutions to develop constructive relations. Apart from the interests which are common to all states that is, to ensure sovereignty and territorial integrity of a country - states cooperating for a long time have also other aims related to the welfare of their citizens, economy, ecology, culture, law and values of more global origin: respect for human rights, rule of law and democracy. These objectives are distinctive features of a cooperative security system. Non-democratic states might work together with democratic ones and even attain satisfactory results in political and military fields. In a longer perspective, through changing interests and common understanding, cooperation might even prompt democratization of non-democratic countries ${ }^{43}$, however, most often cooperation between democratic and non-democratic states is only temporal and is maintained as long as it satisfies interests of both sides. It is likely that cooperation with countries, which do not match the criteria of cooperative security, in the meanwhile will be executed in the framework of ad hoc coalitions formed as a response to a specific threat. The USA Deputy Secretary of Defense Paul Wolfowitz has emphasized that the character of the mission has to determine the composition of the coalition, there can be no single coalition for different missions, different missions should be fulfilled by different coalitions. A key for the success is a flexible and effective coalition $^{44}$.

Ad hoc coalitions might also work as a proper solution in the cases when the

\footnotetext{
${ }^{41}$ Keatinge (note 29$)$ p. 34.

${ }^{42}$ Rotfeld A.D., "Introduction: Global Security after 11 September 2001", SIPRI Yearbook 2002, p. 10 .

${ }^{43}$ Cohen, Mihalka (note 31) p.38.

${ }^{44}$ Van Ham, Kugler (note 6) p.10.
} 
risk is difficult to predict and evaluate, for example, uncontrolled proliferation of nuclear weapons, civil wars, disturbances of the flows of vital resources, terrorist attacks, sabotage and ecological catastrophes. Because these challenges might arise at any time at any place, it would be very difficult and expensive to establish permanent institutions to deal with them.

European countries may also turn to ad hoc coalitions if EU and NATO structures are not adapted to new security needs. In 1997, the EU failed to agree upon the decision regarding the intervention to Albania. The major reason of this failure was the fact that Great Britain and Germany were not concerned with this conflict. Italy, France, Greece, Romania, Slovenia and Turkey (with the participation of Denmark, Austria and, at the end of the operation, Belgium) eventually had to form an ad hoc coalition of willing outside the EU framework, which in a close cooperation with the UN and the OSCE conducted the operation Alba. The military campaign in Afghanistan and Iraq were also conducted avoiding institutional structures of NATO.

Summarizing, it should be stated that at the regional level European security will basically depend both on the actions of the states which only partly belong to the region (the USA and Russia) and also on the success of the cooperation among European countries and betveen multilateral organizations. The effectiveness of the cooperative security system will also be influenced by coordinated and effective activities of major European security institutions, where the most important variables might be: the results of NATO modernization and enlargement, evolution and efficiency of European Common Security and Defense Policy (CSDP) and, finally, the consequences EU enlargement. These processes are discussed in two last chapters of the article.

\section{Modernization and enlargement of NATO}

In the meanwhile, NATO remains the only effective security organization in Europe. The future of CSDP is still vague, the OSCE and the UN lack unity, capacity and effectiveness to solve problems of contemporary security.

At the individual security level NATO states not only ensure the security of their citizens, but also take care of the promotion of human rights outside the Alliance. Seeking to stop violations of human rights in Kosovo, NATO conducted a military campaign. On the other hand, cooperating with countries of unstable regions, NATO indirectly prompts them to adhere to the major principles of democracy and respect human rights.

Assuming that liberal democracies do not fight among themselves, the restrictive function of the collective security level might be eliminated in the European cooperative security system. On the other hand, after EU and NATO expansion to the regions where democracy is still extremely fragile, the situation might change. The collective security level will gain importance if Russia, the Ukraine or other important players on the regional scene, which due to objective obstacles so far cannot become full members of those organizations, are included into the structures of the organization on a partial basis.

Collective defense in NATO still might be imposed relying on the 5th Article of the Washington Treaty. Although for the first time this article was applied only after the terrorist attacks of September 11, hence it was applied already in new circumstances - a further application of this article might become problematic. The 
major challenge of XXI century post-modern threats is an object of the 4th Article of the Washington Treaty. The imposition of this article for the collective defense however might be complicated because of the lack of an imperative norm.

The North Atlantic Cooperation Council (NACC) and the Euro-Atlantic Partnership Council (EAPC), which was created on the basis of the former, the NATORussian Permanent Joint Council (PJC) and the recently established the NATO Russian Council, also the NATO - Ukraine Joint Commission, the Mediterranean Dialogue are perfect examples of institutional arrangements illustrating NATO's aim to promote stability outside the borders of the organization. To achieve this aim, the Alliance also uses other instruments. Most common are crisis management, the Partnership for Peace Program (PfP) and the Weapons of Mass Destruction Initiative (WMDI). Moreover, NATO enlargement proves that NATO seeks to involve more initiatives related to the promotion of stability outside the borders defined by the 6th Article of the Washington Treaty ${ }^{45}$.

Although NATO activities embrace all rings of security and it has all chances of becoming the cornerstone of the European cooperative security system, NATO also faces a lot of problems, which result from the inconsistency of old Cold War instruments and structures with the new functions of security policy. These problems raise doubts about the ability of NATO to effectively fight against the challenges for European security in the future.

In the Rome NATO Summit of 1990 it was announced that Europe entered a new era ${ }^{46}$ and that the new Europe needed NATO of a new quality. On the other hand, the former US Defense Secretary William Cohen declared that one of the most important tasks of the contemporary security organization - peacekeeping - was not the main mission of the US armed forces, nor was it a major task for the majority of NATO members. Peacekeeping missions requested a different preparation and different capabilities ${ }^{47}$. NATO was not ready to deal with the new challenges. First of all, due to the lack of peacekeeping instruments, NATO has become incapable of ensuring a full cycle of security policy. Secondly, NATO's ability to fight against yet another dangerous challenge of the present time - proliferation of weapons of mass destruction - is also doubted. Thirdly, NATO's activities are limited by the definition of the 5th Article, thus, if NATO seeks to provide an adequate response to contemporary threats, it has to take into consideration the global character of threats and become an organization capable of acting globally. Nevertheless, the Alliance still does not possess legal possibilities to act in territories outside the space of the Allian-

\footnotetext{
${ }^{45}$ Article 6: For the purpose of Article 5, an armed attack on one or more of the Parties is deemed to include an armed attack:

on the territory of any of the Parties in Europe or North America, on the Algerian Departments of France, on the territory of Turkey or on the islands under the jurisdiction of any of the Parties in the North Atlantic area north of the Tropic of Cancer;

on the forces, vessels, or aircraft of any of the Parties, when in or over these territories or any area in Europe in which occupation forces of any of the Parties were stationed on the date when the Treaty entered into force or the Mediterranean Sea or the North Atlantic area north of the Tropic of Cancer.

The North Atlantic Treaty, Washington DC, 4 April 1949.

${ }^{46}$ NATO Press Releases, http://www.nato.int/docu/comm/49-95/c911108a.htm

${ }^{47}$ Press Advisory: Basic Publications (note 8).

${ }^{48}$ Lindley-French, (note 19) p. 39.
} 
ce. Finally, an imperfect structure of NATO has become a major obstacle for its efficiency ${ }^{48}$. Deficiencies in the structure have especially elucidated during the military campaign in the Balkans. Therefore, seeking to guarantee effective and flexible actions in Afghanistan the US made use of the capabilities of allies avoiding bureaucratized political structures of NATO.

Seeking to retain defensive capabilities of the Alliance, reforms of military command structures and measures were introduced in the last decade of XX century. It was envisaged to implement the reforms in several directions: mobility, logistics, permanence and effective functioning, command, control and informational systems. In 1994, to implement the new tasks the Combined Joint Task Force (CJTF) was endorsed. The same year NATO started the Partnership for Peace program (PFP), which envisaged a cooperation in the military field between NATO and non-NATO countries. The formation of a mobile, flexible Rapid Reaction Force was started, of which the Allied Common Europe (ACE), Mobile Force (AMF) and the ACE Rapid Reaction Corps (ARRC) were especially important for Europeans. Forces for peacekeeping were planned to be established in the framework of European Security and Defense Identity (ESDI), providing lightly armed European forces with the functions of civil administration, police, conflict management, election organization and observation, and, finally, monitoring of the media ${ }^{49}$. The Washington Summit proposed the Defense Capabilities Initiative (DCI) aiming to improve NATO's capabilities adopting them for crisis management functions. NATO Summit in Prague in November of 2002 was also concentrating on basically two issues: what is the mission for NATO in XXI century and what is the most proper structure for the new tasks. The emphasis was made on new command structures, which earlier were based on geographical responsibility and now require more flexibility and mobility.

The actions taken by NATO to respond to the new problematique of security were positively assessed in NATO's New Strategic Concept ${ }^{50}$; however, it is worth admitting that the perspectives of the Alliance to become an organization of cooperative security are still vague and will depend not only on the success of further reforms of organizational structures but also on other factors.

One of the most important variables to influence the efficiency of the organization is the relationship between the USA and European allies. Strategies on how to respond to global challenges and threats differ in the USA and Europe. Frequently Americans and Europeans tend to even define challenges, risks and threats different$\mathrm{ly}^{51}$. One of the main causes of these variations is the constantly increasing gap between Europeans and Americans in the field of modern technologies. All NATO countries reduced their defense expenditure and military capabilities after the Cold War. However, due to the advantages of the effective distribution of the defense budget in the USA, the power of the USA military forces has not decreased. Europeans are lacking far behind almost in all fields of military capabilities. This gap might become a serious obstacle for the interoperability between the allies even in the framework of NATO.

\footnotetext{
49 "ESDI: Right Debate, Wrong Conclusions" Press Advisory: Basic Publications 8 September 2000, http://www.basicint.org.ciuunits.htm

${ }^{50}$ Howorth J., "European integration and defence: the ultimate challenge?, Chaillot Paper No.43, 2000 November, p. 27.

${ }^{51}$ Van Ham, Kugler, (note 6) p. 20.
} 
In Afghanistan the cooperation between the USA and the allies was based on bilateral agreements rather than on NATO structures. One of the reasons forcing Americans just minimally rely on the support of its allies was that Europeans did not have sufficient capabilities required by the USA for this operation. Although after almost a decade of reforms European armed forces are larger and more efficient than they used to be several years ago, because of the prioritization of the territorial defense, Europeans still lack capabilities to be used to deal with new threats.

The division of labor between Europeans and Americans in Bosnia, where Americans acted in the initial stages of the conflict and were making the most important decisions, whereas Europeans were just fulfilling peacekeeping tasks, is often illustrated with an example of "making a dinner" and "washing the dishes" 52 and frequently causes disagreements between the allies. Americans call Europeans "free riders". Europeans are not satisfied with unilateral actions of Americans. On the one hand, Americans are right when accusing their allies in Europe for feasibility, on the other hand, labor division does not have to allow the asymmetry of the political power where Americans make use of the power of global decision-making and Europeans can only support the unilateral policy of the USA. Hence, if the NATO structure is not reformed to provide Europeans with the ability to form flexible coalitions and take a more active part when solving security problems of the region, they may turn away from NATO, transferring the cooperation into EU structures or starting to form ad hoc coalitions. Still, as NATO is the only possibility for Europeans to retain USA military capabilities in Europe, which are vitally important for Europeans, it is unlikely that Europeans would be the ones to withdraw from NATO. On the other hand, if the majority of military operations rely on ad hoc coalitions, with the USA involved, NATO might become rather a political organization than a collective defense alliance. Even though it fulfills just political functions, it can still play an important role in changing the strategic map of Europe with the help of non-military means.

Julian Lindley-French believes that aiming to solve the main problems of NATO concerning the USA - EU relations, first of all fruitful consultations between the Alliance partners where both parties are provided with equal power have to be restored. Secondly, Europeans have to have the ability to command not only over entirely European missions, but also over those in which Americans are taking part. Therefore, NATO structures have to be reformed. Thirdly, EU and NATO planning structures have to be coordinated. Fourthly, Great Britain or France has to take leadership in European missions ${ }^{53}$.

The success of NATO modernization and effectiveness will inevitably rely upon the consequences of NATO enlargement. The inability of candidates in capabilities domain might become a burden for the Alliance. Because the candidate states essentially continue to rely on the principle of territorial defense, problems might also arise in threat assessment. It could be very difficult to the political elite of those countries to convince their voters that their country, instead of defending its own

\footnotetext{
${ }^{52}$ Kagan, (note 14$)$.

${ }^{53}$ Lindley-French, (note 19) p. 66.

${ }^{54}$ Vershbow A., "NATO enlargement" Department of State, Washington, file, Krakow, June 2000,

http://www.nato.int/usa.ambassadors/s20000607.htm

${ }_{55}$ Rotfeld, (note 42) p.9.
} 
people and land, has to reorient its defense strategy to fight global threats. Although it is obvious that new members will not bring significant military resources into the Alliance, the process of the enlargement is an essential part of the Alliance's strategy aiming at uniting and stabilizing Europe ${ }^{54}$. The membership of Bulgaria, Estonia, Latvia, Lithuania, Romania, Slovakia and Slovenia will widen the area of political stability in Europe. Moreover, the inclusion of some of new members (Romania, Bulgaria) will transfer NATO infrastructure closer to problematic regions ${ }^{55}$, thus ensuring better conditions to fight threats stemming from those regions.

Seeking to evaluate the perspectives of the enlargement, a few important factors are to be taken into account. First of all, the volume of the enlargement will expose a direct influence on the internal structure of NATO which will have to be reformed. The impact of those reforms on the effectiveness of NATO is still unclear. The reforms of NATO command structures that have already started are not always estimated in such a positive light as they have been assessed in the New Strategic Concept though. Karl Feldmeyer has noticed that reforms in NATO instead of an objective aim to improve military efficiency often become a reflection of redistribution of political influence among its members ${ }^{56}$. It is even more complicated to predict consequences of further implementation of reforms after new members join the Alliance: having more members, it would be more difficult to reach a consensus. NATO's capability to retain dynamism and effectiveness will depend not only on the ability of members to reform defense structures, foreign and defense policies, but also on economic perspectives and social political coherence in candidate countries $^{57}$. NATO enlargement will stimulate the already existing problem of free riding. Moreover, the behavior of new members does not allow one to hope that the problem will be solved soon. Entering NATO, Hungary has obliged itself to increase defense expenditure up to 1.8 per cent of GDP (although the requirement of NATO was 2.0 per cent); however, in 2001, according to SIPRI data, it hardly reached 1.3 per cent ${ }^{58}$. On the other hand, this data does not tell if these resources were used effectively. NATO experts note that armed forces of new NATO members (the Czech Republic, Hungary and Poland) are insufficiently financed and, in most cases, are not ready for common actions with NATO ${ }^{59}$. It is worth mentioning that the Czech Republic, Hungary and Poland are the most economically developed states in Central and Eastern Europe. The support for the Alliance in these states was also one of the highest in the region. Yet it is hard to predict the hardships Romania and Bulgaria might cause in the domain.

After the NATO ministerial meeting in Reykjavik, which was held on 14-15 May 2002, the NATO-Russian relations entered another stage. The NATO-Russian Council started its activities on the 28th of the same month. It was agreed that NATO members and Russia would cooperate as equal partners in the areas of common

\footnotetext{
${ }^{56}$ Croft S., "Guaranteeing European Security?: Enlarging again", International Affairs 78 (1), 2002, p.105.

${ }^{57}$ Croft, (note 56) p.110.

${ }^{58}$ Croft, (note 56) p.105.

${ }^{59}$ Lokewood Ch., Butcher T. "NATO puts plans eastward enlargement on hold.”, Daily Telegraph, 3 April 2000.

${ }^{60}$ Ministerial Meeting of the North Atlantic Council, Final Communique, Reykjavik, May 14, 2002.
} 
interests, however retaining prerogative of NATO to act independently ${ }^{60}$. NATO would have an absolute autonomy when dealing with collective defense issues, though the majority of the 4th Article issues would be solved in cooperation with Russia and taking its interests and opinion into account. The NATO-Russian Council made a very positive start in six months it has been in action. There was an observable willingness on the Russian side to participate in the activities of the Council. The inclusion of Russia into NATO structures undoubtedly brings NATO closer to the cooperative security model, however, it is still difficult to claim that a warm-up in the Russian-NATO relations is a long-term occurrence. Russia has not made a clear message what exactly it expects from the Council. The enlargement of NATO, especially the membership of the Baltic countries, might bring into light problems related to the negative attitudes in the Russian society towards the Alliance and its expansion and hereby pro-Western orientation of Russia. Reconsideration of the directions of security and foreign policies of the Russian Federation would undoubtedly influence the activities of the NATO - Russian Council and would have reflections on the overall efficiency of the Alliance. On the other hand, it has not to be allowed that the Russian involvement into NATO decision-making processes would turn the Alliance into an ineffective organization of collective security similar to the OSCE or the Council of Europe, whose members are incapable of adopting common decisions even on very broad issues.

Summarizing the main directions of NATO reforms, it might be concluded that aiming to adapt to the new security environment, the Alliance has changed both internally and externally. And still, to become a flexible cooperative security organization, it has to solve many important issues. First of all, NATO has to continue structural reforms and prevent the use of reforms for the expansion of influence. Secondly, the solution of the $5^{\text {th }}$-Article problem would considerably increase the effectiveness of the organization. Thirdly, if NATO members decide, that peacekeeping missions are not a task for the Alliance and leave them for the EU, common structures for the coordination of different instruments and functions of security policy would be necessary. Fourthly, the future of NATO will depend on its ability to solve problems concerning the USA - EU relations. Fifthly, a successful enlargement, although probably decreasing the effectiveness of the organization in a short term, in a longer perspective would enhance the capabilities of NATO and its involvement in the cooperative security system. Finally, the strengthening of the structures for the cooperation with non-member countries would create a favorable environment not only for the maintenance of security outside the organization, but also would work as a wonderful basis for common activities fighting global threats.

\section{Security and Defense Identity of the European Union}

The growth of economic welfare, consolidation of common values and similarity of traditions in Europe became an important reason prompting European countries to seek for even deeper integration. An exclusive position of foreign policy was challenged. Since 1986, coordination of foreign policy was carried out in the framework of the European Political Cooperation (EPC). Yet in Maastricht it was formalized with the creation of the second pillar of the EU: Common Foreign and Security Policy (CFSP). The inclusion of Common Security and Defense Policy (CSDP) into 
CFSP might be estimated as an inevitable necessity to supplement the already existing political/diplomatic and economic/commercial instruments of the EU with a security dimension and instruments of defense policy. On the other hand, it was a response of Europeans to the accusations of Americans for an insufficient involvement of Europe in security issues. ESDI (in the framework of NATO) proposed by the US in 1994 and CSDP envisaged in Maastricht were expected to become the cornerstones of the new European security system. However ESDI (in the framework of NATO) did not retain its significance. Moreover, after the St. Malo meeting in 1998, the process of the CSDP development gained a double speed, therefore compelling the skeptics of it to recognize that the perspectives of CSDP were not totally hopeless.

The Cologne European Council agreed to transfer WEU functions to the $\mathrm{EU}^{61}$. In Helsinki decisions on the establishment of European Rapid Reaction Forces (RRF) were adopted. Agreeing on the Headline goal Europeans committed themselves by the year 2003, cooperating together voluntarily, to be able to deploy rapidly and then sustain forces capable of the full range of Petersberg tasks ${ }^{62}$ up to 15 brigades or 50,000-60,000 persons. Member States should be able to deploy in full at this level within 60 days, and thus to provide smaller rapid response elements available and deployable at a very high readiness. They must be able to sustain such a deployment for at least one year ${ }^{63}$. In Leaken these forces were announced capable of conducting some crisis-management operations ${ }^{64}$. In Copenhagen it was also agreed to take over peacekeeping functions in Bosnia and Macedonia. It was expected that RRF would be announced operable by the beginning of 2003, however the issue of operability was delayed for the summer. In December of 2002 a NATO and EU agreement on CSDP was reached. The EU has acquired the right to use the infrastructure of NATO for its missions.

After the introduction of the security and defense dimension the European Union ceased to be simply an economic block and became a real security organization. However, prospects of CSDP, which is still under formation, are difficult to foresee. A lot of various factors related both to the evolution of the EU and also the international environment may influence a further development of CSDP. Still, it is worth noting that the EU already has capabilities to ensure necessary instruments in all rings of security. EU countries, the majority of which are also NATO members, attract special attention to the issues of human rights inside and outside the organization. Constant EU aid for the Third World countries or states in conflict, reconstruction funds flowing from EU just reaffirm the fact that the EU takes an active role in ensuring security at the individual level. Comparing the EU and NATO, it is worth

\footnotetext{
${ }^{61}$ Cologne European Council, Presidency Conclusions,1999, http://europe.eu.int/council/off/conclu/ index.htm

${ }^{62}$ In 1992 WEU countries signed a Petersberg Declaration declaring their readiness to make available military units to implement so called Petersberg tasks containing humanitarian tasks, rescue tasks, peace-keeping tasks and tasks of combat forces in crisis management. http://europa.eu.int/scadplus/leg/en/cig/g4000p.htm

${ }^{63}$ Helsinki European Council Presidency Conclusions, 1999, http://europe.eu.int/council/off/conclu/ index.htm

${ }^{64}$ Laeken European Council Presidency Conclusions, 2001, http://europe.eu.int/council/off/conclu/index.htm
} 
mentioning that there is an obvious division of labor between the two organizations also on the individual security level: NATO basically using military means and the EU taking the responsibility for non-military aspects.

Moreover, it is likely that as EU common identity, in general terms, grows stronger, it will also strengthen defense identity. On the other hand, as the significance of post-modern non- $5^{\text {th }}$ Article threats emerging from the regions remote from Europe is increasing in the contemporary world, it could be possible that instruments to ensure security provided by CSDP will be more relevant than those of NATO even in terms of collective defense.

After the Cold War it was understood that security was indivisible and it could only be attained if all members of the system (or at least of a security complex) were participating in common efforts to ensure security. Seeking to promote stability and security in the regions outside the organization, the EU was constantly carrying out a lot of programs of economic aid, cooperation and development. Promoting stability outside the region became a long-term EU strategy. After the dissolution of the SSSR, European Communities signed cooperational agreements with former Republics of the Soviet Union and members of the former Warsaw Treaty Organization ${ }^{65}$. Political radicalism and constantly growing migration from Northern Africa forced Southern EU countries to seek for a common preventive strategy, which would neutralize undesirable consequences of those processes. In 1995, the Euro-Mediterranean Partnership Council was established in Barcelona aiming to enhance cooperation between the EU and other states of the region. States participating in the initiative ${ }^{66}$ signed an agreement for the cooperation in military, economic, financial, cultural and other areas. Seeking to ensure stability in the region, EU countries also decided that unification of Europe was an open process accessible for all nations of Europe sharing the same interests and objectives ${ }^{67}$. Hence, EU enlargement becomes an important factor in itself in ensuring security and stability in Europe.

The EU has extended its security building measures. It already operates in all rings of security. Therefore, it is reasonable to believe that CSDP and the EU (as an organization) have big chances of becoming a key element of a cooperative security system in Europe. However, further perspectives of CSDP will also depend on how the EU will solve problems related to the internal aspects of the organization, its relations to other countries and other international organizations.

Decisions of Cologne, Helsinki and the later European Councils committed EU members to take part in defensive non- $5^{\text {th }}$ Article military operations in the framework of Petersberg tasks. However, the existing definition of Petersberg tasks is very ambiguous and therefore might negatively influence the development of CSDP and even endanger security of the region. Problems of the definition of Petersberg tasks might be divided into two parts: ambiguity of the territorial commitment and

\footnotetext{
${ }^{65}$ Agreements on trade, economic and commercial co-operation were signed. Later these agr. were changed by Europe (Association) Agreements. In 1995 in Paris European Stability Pact was signed aiming to enhance co-operation among Central and Eastern European countries and promote their dialogue with the Western states.

${ }^{66}$ Agreement was signed by EU on one side and Algeria, Cyprus, Egypt, Israel, Jordan, Lebanon, Malta, Morocco, Syria, Tunisia, Turkey and authorities of Palestine on the other. Keatinge, (note 31) p.19.

${ }^{67}$ Los Nowak. T., "Euroregions as an European Identity creating factor: premises, possibilities, jeopardies", Copri papers, http://www.copri.dk/copri/downloads/25-2000.doc

${ }^{68}$ Croft, (note 56) p.102.
} 
vagueness of the content of future operations. Scenarios of the deployment of European military forces have been under discussion since 1995. A possible distance of future operations varied from 2,000 to 6,000 km distance from Brussels. It means that the closest operations would not extend eastern boarders of the enlarged EU, the farthest yet might reach Afghanistan, Middle Asia, etc. ${ }^{68}$ The character of future missions according to the existing Petersberg tasks definition is also very vague and might involve even big-scale conflicts, such as the Gulf War. It has to be noted that very diverse both in terms of quality and quantity capabilities would be necessary in those circumstances. Only when the problem of the definition is solved, it will be possible to estimate how much and what kind of capabilities the EU has to create and, finally, what institutional structure is the most proper to coordinate these operations.

The process of the enlargement happening in parallel with the internal reforms of the EU will inevitably influence the further development of CSDP. Two important aspects of the enlargement are to be underlined. The first one is financial problems related to EU internal reforms and the inclusion of relatively economically weak candidate countries. The second one is the problem of stability rising because of the territorial expansion of the EU. Too fast an enlargement might weaken the institutional power of the EU and also its economic and political stability. Thus, the solution of external security challenges by integrating unstable regions into the EU will, on the other hand, bring in new risks: migration of delinquency, economic and social inequalities, which might stipulate conflicts and so on. Most of candidate countries are experiencing economic difficulties, whereas democracy in those countries is not as stable as it used to be assumed earlier ${ }^{69}$. The fear of tanks and missiles coming from the other side of the Iron Curtain has changed to the fear of an uncontrolled migration and threat of international crime ${ }^{70}$.

Another important problem lies in the fact that EU enlargement brings EU borders closer to unstable countries. The admission of Poland, Slovakia and Lithuania would bring the EU closer to the Ukraine and Belarus, the membership of Cyprus would cause a direct contact with the Middle East. The inclusion of Turkey (if possible at all) would make Syria, Iran and Iraq EU neighbors. The extension of borders may involve EU countries into long-lasting and costly conflicts with unstable neighbors and therefore negatively influence the stability of the region.

Th e

EU readiness to deal with unpredictable crises is also an important variable judging the prospects of the Union to become a cooperative security organization. However, the effectiveness of measures might be reduced by the principles of intergovernmentalism and unanimity incorporated in the second pillar of the EU. Most of security analysts recognize that an efficient CSDP is possible only if supranationalism and the majority vote are introduced instead or one of EU members takes a leading role. Although this scenario of EU development is hardly possible at least in a short term, in order to neutralize at least some of the problems posed by intergovernmentalism and unanimity, the principle of constructive abstention was introduced in Nice ${ }^{71}$.

\footnotetext{
${ }^{69}$ Winn, (note 30) p.79.

${ }^{70}$ Grabbe H., "The Sharp Edges of Europe: Security Implications of Extending EU Borders Policies Eastwards”, Occasional Paper No.13, 2000, p.7.

${ }_{71}$ Treaty of Nice, Brussels, 14 February 2001, SN1247/1/01 REV1. Art.24(3).

${ }_{22}$ Duff A., Treaty of Amsterdam, EU: Federal Trust for Education and Research, 1997, p.117.
} 
Constructive abstention guarantees a right for member states to abstent when voting on the initiatives which are not acceptable for them, thereby avoiding blocking of a decision. The principle of enhanced cooperation, which provides a group of states with an opportunity to seek for a deeper integration in foreign and security policy domain even if there is no clear consensus in other areas ${ }^{72}$, may also provide with at least a partial solution of the problems caused by intergovernmentalism and unanimity. On the other hand, it is often argued that the Nice Treaty granted even more power to the largest states of the EU and Euro-bureaucrats that may in time prompt fragmentation of the EU and challenge its efficiency, therefore the general impact of this treaty on CSDP might be controversial.

One of the most important problems of CSDP is insufficiency of military capabilities which manifested itself in the Balkans. Americans estimated the activities of European allies in Kosovo in an extremely negative light ${ }^{73}$. They resumed that Europeans were experiencing major difficulties in the mobility of armed forces, also in the areas of command, control and communications. Conflicts in the Balkans also brought into light deficiencies in strategic intelligence, anti-missile defense, airlift, precision guided missiles and other fields related to modern technologies. Europeans even failed to provide a sufficient amount of military personnel and conventional weapons.

The lackage of military capabilities in Europe is a result of insufficient financing and improper distribution of the defense budget. In 2000 defense expenditure in the USA was 296,373 million USD, which estimated 3 per cent of GDP, total defense expenditure of European allies was just 164,559 million USD and respectively estimated 2.1 per cent of the average GDP ${ }^{74}$. Although eight EU NATO members increased their defense expenditure in $2001^{75}$, an essential improvement of European capabilities was not observable mainly because the distribution of money was still far from perfect. The biggest share of defense budgets in European countries was assigned to finance oversized and technologically outdated armies; on the other hand, large share of the defense budget in the US was invested in modern technologies. In a longer perspective these shortcomings may not only make Europeans incapable of acting independently, but also threaten to complicate the interoperability of European and American armed forces in common actions. EU capabilities to assure sufficient financing for CSDP are still vague.

The implementation of the Headline goal alone will cost Europeans several billion USD each year. It is also worth mentioning that real costs of the Headline goal will be quite bigger than it was expected earlier. Due to rotation and selection of soldiers, military personnel required to participate in different missions will increase from 50,000 - 60,000 to 200,000 - 230,000 soldiers; consequently, the amounts of the necessary logistics, military equipment and other capabilities will also increase. Moreover, it is hardly expected that this problem will be solved before EU countries significantly increase their defense budgets and reconsider distributional strategies.

\footnotetext{
${ }^{73}$ Smith I. D., "Evidence to the Committee on International Relations, House of Representatives", Wednesday 10th November, 1999.

${ }^{74}$ NATO Handbook, Brussels: NATO Office of Information and Press, 2001

${ }^{75}$ Grant Ch., "A European view of ESDP", http://www.eusec.org/grant.htm
} 
The largest armies in Europe, i.e. those of Germany, Greece and Italy, in sum possess 760,000 soldiers, which estimates more than 55 per cent of the US armed forces. However, the money that is assigned for the armaments in these countries estimates just 10 per cent of this spent by the US. The EU expenditure for scientific research amounts only one fourth of the American expenditure and basically is the money of Great Britain and France. According to the data of the Institute of International Strategic Studies, Europeans would need at least 35 billion USD in the upcoming decade just to reduce the gap which exists between the armed forces of EU and the USA. In 2002 the US again increased its defense budget and plans to allocate 3.7 per cent of GDP for military purposes, yet the EU stays far behind with only 2 per cent of GDP ${ }^{76}$. The gap between Europe and USA military capabilities is likely to remain increasing in the future and, if not considered, might become a serious challenge for the EU, NATO and the stability of the whole region.

Although European politicians are convinced that commitments of the EU are not as global as those of the USA (Asia and the Middle East) and the implementation of European missions will require less resources than USA operations, expanding closer to unstable regions and trying to protect its members, the EU, even against its will, might get involved in conflicts demanding enormous resources. In addition to interoperability challenges, the issues of coordination of actions and resources have also to be addressed. The Berlin Communiqué envisaged the WEU access to NATO assets, which was later confirmed with the "Berlin plus" formula ${ }^{77}$. This formula, however, provides just a partial solution of the capability problem and would be of no use if NATO resources were needed by Americans to fight global threats. On the other hand, due to insufficient and improper financing of military capabilities, Europeans may become incapable of acting together with Americans.

Trying to reduce the gap between the USA and EU states, also to adapt European armed forces to the new missions which require flexibility and mobility, Europeans were fulfilling reforms of their armed forces: France in 1994 - 1996, Germany in 1994 - 2000, Sweden 1995 - 1999, Great Britain in $1993-1998 .^{78}$ The main objective of these reforms was creation of small professional armed forces equipped with modern armaments giving up the dependence on conscription. French armed forces became fully professional in 2002. Great Britain, Belgium, the Netherlands and Luxembourg also have fully professional armies. The numbers of conscripts were significantly reduced in Spain and Italy ${ }^{79}$. Reforms are still going on in other EU countries.

\footnotetext{
${ }^{76}$ Heisbourg F., "European Defence Takes a Leap Forward”, NATO Review, 48 (1), 2000. p. 97. ${ }^{77}$ Decisions were taken in Berlin in 1996 to cover NATO support for operations led by the WEU, known as the "Berlin arrangements". In 1999 new arrangements for EU known as "Berlin Plus" were agreed upon, which are wider and deeper than those for the WEU. The Berlin Plus package consists of four elements: 1) assured EU access to NATO operational planning, 2) presumption of availability to the EU of NATO capabilities and common assets, 3) NATO European command options for EU-led operations, including DSACEUR, 4) adaptation of NATO defense planning system to incorporate availability of forces for EU operations. http://www.nato.int/uk/docu/esdi.htm

${ }^{78}$ Andersson J.J., "Cold War Dinosours or Hi-Tech Arms Providers? The West European Land Armaments Industry at the Turn of the Millenium”, Occasional Paper No.23, 2001, p.6.

${ }^{79}$ Grant, note (75).

${ }^{80}$ Lindley-French, (note 19) p.10.
} 
Positive results of those reforms already became visible in the Balkans in 2002. European countries provided 60 per cent of armed forces in Bosnia and Kosovo, while the share of the USA was approximately 20 - 25 per cent. Moreover, the behavior of European units was recognized as very efficient ${ }^{80}$. Thus, despite still large shortcomings in the field of military capabilities, European armed forces already show positive trends in dealing with the challenges of the contemporary world.

The problems of military capabilities are closely related to the difficulties experienced by the European defense industry. Key challenges in the domain are: the fragmented structure of the industry, conflicting interests and the insufficient market. Although some positive trends might be observed in this field (in 2002 Great Britain, France, Germany and Italy established the Organization for Joint Armament Cooperation (OCCAR), in 1998 the Memorandum of Intentions on the coordination and harmonization of some fields of defense policy and procedures was signed by Sweden and Spain, major European defense industry companies are consolidating (EADS, BAE Systems, etc.), Europeans are not yet able to compete with Americans.

An effective system of cooperative security in Europe is impossible without the participation of Russia. European security is tightly linked not only to the foreign policy of the Russian Federation but also to the consequences of still happening processes of democratization and transition to market economy. If the USA reallocates the majority of the resources to fight global threats, Europeans might become too weak to solve regional problems. Therefore, especially in dealing with post-modern regional threats, Russia is becoming crucially important to the $\mathrm{EU}^{81}$. Both Russia and the EU recognize the advantages of cooperation in the areas of security and defense. The Russian-EU relations in the domain are constantly intensifying and changing their format. If earlier Russia tended to deal with European countries on a bilateral level, now more often it addresses the European Union as a single entity. During the EU-Russia Summit in October 2000, the EU announced that it was willing to enhance the dialogue and cooperation with Russia on security and defense issues. Participants of the meeting agreed to establish special consultations and develop a strategic dialogue on security issues important to the EU and Russia, elaborate consultations in the fields of arms reduction, arms control and non-proliferation and, finally, to develop cooperation in crisis management. The most recent cooperational initiatives are on fighting terrorism, organized crime and proliferation of WMD.

The cooperation between the EU and Russia has not excluded defense industry. Until recently Europeans have not been much interested in aeronautics and satellite technology, there were neither big-scale programs nor infrastructural basis to implement these programs in Europe. However, the situation changed in 2000 with the establishment of the European Aeronautic Defense and Space Company (EADS). Moreover, developing its activities, in 2001, the EADS together with the Russian Aerospace Agency signed the Strategic Partnership Agreement in which both parties agreed to pool joint resources to implement certain projects.

Nevertheless, for a further and closer cooperation political will in Russia and the EU is necessary. Reforms of military structures in both technological and ideological sense have to be fulfilled; major changes in defense industry have to be introduced. The future of the EU - Russian relationship will also depend on what role in the

${ }^{81}$ Kremenyuk, (note 22). 
European security architecture Europeans plan to propose for Russia.

Although after September 11 the importance of CSDP is frequently underestimated, it might be presumed that sighnificance of CSDP increased. First of all, a successful development of CSDP would let Americans to concentrate on fighting terrorism. Secondly, the significance of Petersberg tasks, which are the main responsibility of CSDP has increased after the terrorist attacks in New York and Washington DC. Immediately after September 11 the High Representative for CFSP Javier Solana affirmed the EU anti-terrorism program ${ }^{82}$, which shows that the organization effectively reacts to the changes in international security environment. Moreover, the anti-terrorism program envisaging a wide range of new instruments could prompt the development of CFSP and CSDP.

Nevertheless, despite major achievements in developing CSDP and CFSP in the political and security domains instead of relying on EU institutions, EU states are still more willing to behave unilaterally. Thus, there is still much to be done to ensure a further progress of CSDP and to strengthen its position in the European security architecture. Future opportunities of CSDP will inevitably depend on the EU success in clarifying the definition of Petersberg tasks, solving problems posed by intergovernmentalism and unanimity and, finally, the success in providing sufficient military capabilities. On the other hand, the destiny of CSDP will also be influenced by the results of EU cooperation with NATO, the USA and Russia.

\section{Conclusions}

Changes in the international system and security problematique resulted in the reconsideration of the prospects of European security in the newly emerging international order and the search of the most proper means to ensure security in the region. European countries are facing the threats that are stemming externally, therefore european security will depend on common efforts and the success of center states aiming to neutralize negative consequences of globalization, results of cooperation between center and periphery states in political, economic and security areas, behavior of Russia and, finally, on the success of the USA military forces fighting threats of military origin. Thus, in the military domain the strengthening of the transatlantic link has to become one of the major priorities of the EU. The future EU-US cooperation is likely to be based on the division of labor, taking advantage of the fields in which countries have the best capabilities. Probably, the cooperation with Russia will also be structured on the same scheme, where joint activities of Russia and European countries will cover the areas of EU responsibility ("soft" security issues and regional cooperational initiatives).

On the regional level, prospects of European security are closely related to the future behavior of the countries only partly belonging to the region (the USA and Russia), that is, what roles they will play in the regional security system. On the other hand, a lot will depend on cooperational perspectives of European countries. Security of the contemporary Europe on the regional level therefore is likely to rely on the

\footnotetext{
${ }^{82}$ European Council (JHA) Conclusions, Brussels, 20 Sept. 2001, SN 3926/6/01 Rev. 6, 20 Sep. 2001
} 
system of cooperative security based on bilateral and multilateral cooperation, covering all interlinked rings of security.

The success of the cooperative security system in guaranteeing European security depends, first of all, on the effectiveness and coordinated actions of major institutions of European security: the EU and NATO. Secondly, it would be inevitably influenced by the results of NATO modernization, enlargement and success in developing structures for the cooperation with non-member countries. Thirdly, proper progressive evolution of CSDP is also crucially important for the effectiveness of the cooperative security system. Therefore, the issues of clarification of Petersberg tasks, alteration of intergovernmentalism, unanimity and strengthening of military capabilities are to be addressed. Externally, the evolution and efficiency of CSDP are inevitably related to the development of the EU-NATO, EU - USA and EU - Russian cooperation.

Aiming to respond to the challenges of XXI century, the institutional system of European security has changed. The emerging system of cooperative security, although yet far from being perfect, is constantly being adapted to the current problematique of security, thereby increasing its ability to ensure security at the regional level. It is still too early to talk about the opportunities of this system in the global domain where there are still many non-democratic and unstable peripheral states, which behave relying on completely different principles from those required by the cooperative security system. Alongside interests that are common to almost all countries - to assure sovereignty and territorial integrity of the state - the countries that participate in the cooperative security system have other aims which might be related to the welfare of their citizens, economy, ecology, culture, law and values of a more global character (human rights, rule of law, democracy). Nevertheless, it is likely that the cooperation, occurring in the framework of the European cooperative security system and changing the rules of security relations, norms of behavior, interests and general understanding of security, may pass onto a more global level in a longer perspective. 